\title{
Postyapısalcı Anarşizm ve Ekoloji
}

\author{
Seçil Mine Türk \\ Gazi Üniversitesi
}

\section{Öz}

Eko-anarşizm bir toplumsal hareket ve ideoloji olarak ekolojinin bir dalıdır. Eko-anarşizmin temel kabulleri en iyi biçimde anarşizmin özgürlük ve eşitlik anlayışı, otorite kavramının anarşist eleştirisi ve doğa ile insan arasındaki ilişki üzerinde düşünmenin önceliğine vurgu yapan ekolojik perspektifin bir bileşimi olarak özetlenebilir. Söylemeye bile gerek yok ki, ekolojik perspektif hem toplumsal hem de siyasal teorinin gelişiminde önemli bir etkiye sahip olmuştur. Bunu yaparken, ekoloji pek çok sosyo-politik konuyla ve sorunla ilgilenmiş ve eş zamanl olarak diğer siyasal hareketler ve ideolojilerle karşılaşmıştır. Bu noktada özü itibariyle bir ondokuzuncu yüzyıl ideolojisi olan anarşizm, kendisini siyasal ekoloji için önemli bir müttefike dönüştürmüş ve bu iki ideolojinin birlikteliği hem anarşizm hem de ekoloji için son derece öğretici olmuştur. Benzeri bir hatta, anarşist teori içindeki postyapısalcı anarşizm gibi yeni perspektifler de bu sürecin gelişmesine anlamlı ve önemli katkılarda bulunmuştur. Bu çalışma, söz konusu eksenden hareketle, postyapısalcı anarşizmin, ekolojik perspektifin kavranabilmesi için bize anlaml firsatlar sunan verimli bir zemin olarak bir tasvirini yapmıştır. Bu doğrultuda söz konusu çalışma iki ana bölüme ayrılmıştır. Birinci bölüm postyapısalcı anarşizmin temel niteliklerine odaklanmış ve bunu yaparken postyapısalcı anarşizmin anarşizmin genel çerçevesi içinde sahip olduğu konum üzerinde düşünmeye çalışmıştır. İkinci bölümde ise postyapısalcı anarşizmin ekolojik bakış açısı üzerinden nasıl okunabileceği üzerinde durulmuştur.

Anahtar Kelimeler: Postyapısalcı anarşizm, eko-anarşizm, ekoloji, anarşizm, postyapısalcılık. 


\title{
Poststructuralist Anarchism and Ecology
}

\author{
Seçil Mine Türk \\ Gazi University
}

\begin{abstract}
Eco-anarchism is a strand of ecology as a social movement and political ideology. The basic tenets of eco-anarchism can be best described as a co-existence of anarchist understanding of freedom and equality, the anarchist critique of the concept of authority and ecological perspective that puts an emphasis on the priority of reflecting on the relationship between human beings and nature. It goes without saying that ecology has an impact on the development of both social and political theory. In so doing, ecology deals with many socio-political issues and problems and simultaneously encounters other political movements and ideologies. At this point, anarchism as a major political ideology emerged in the nineteenth century has transformed itself into an important ally for political ecology and the togetherness of these two ideologies has become very instructive for both ecology and anarchism. In a similar vein, new perspectives such as poststructuralist anarchism within the anarchist theory have contributed to the development of this process. This study has seeked to describe poststructuralist anarchism as a fruitful field for enabling us to find significant opportunities in order to be able to comprehend ecological perspective. Accordingly, the study has been structured into two major parts. The first part focused on the basic characteristics of poststructuralist anarchism and pondered the position of poststructuralist anarchism within the framework of anarchism. The second part examined the problem of how poststructuralist anarchism could be read and positioned from an ecological point of view.
\end{abstract}

Keywords: Poststructuralist anarchism, eco-anarchism, ecology, anarchism, poststructuralism. 


\section{Giriş}

Ekoloji düşüncesi içinde kendisine sıklıkla atıf yapılan düşünsel mecralardan biri de eko-anarşizm olmuştur. Ekolojik düşüncenin farklı tarihsel ideolojilerle girdiği etkileşimin bir uzantısı olarak eko-anarşizm en genel haliyle ekolojik perspektifin anarşizmin temel kabulleri ile örtüştüğü varsayımı üzerine inşa edilmiştir. Davidson'ın da belirttiği üzere, "anarşist fikirler, 1960'ların sonu ve 1970'lerde modern çevre hareketinin ortaya çıkışından bu yana yeşil siyasal düşünceyi güçlü bir biçimde etkilemiştir" (Davidson, 2009, s. 47). Öte yandan ekolojik hareketin teorik zemininde yer alan derin ekoloji ve toplumsal ekoloji gibi düşünsel pozisyonlar dışında, doğrudan eko-anarşizmin doğası üzerine odaklanmış çok zengin bir literatür olduğunu söylemek zordur. ${ }^{1}$

Esasen bu eğilimin büyük ölçüde anarşist literatürün kendisi için de geçerli olduğu söylenebilir. Anarşizmin bir ideoloji olarak Marksist-sosyalist hareketlerle olan tarihsel bağını koparıp bağımsızlaşmasından itibaren, zikredilen hareketi temel alan literatür ile anarşist literatür arasında kayda değer bir fark oluşmuştur. Hiç kuşkusuz bunda Marksist-sosyalist düşüncenin aksine anarşizmin pratik uygulama sahasının tarihsel olarak çok daha kısıtlı kalması önemli bir etkendir. Anarşist hareket çok uzun bir süre boyunca Proudhon, Bakunin, Kropotkin gibi ondokuzuncu yüzyıl anarşizminin kurucu figürlerinin teorik mirası üzerinden ilerlemiştir. Anarşizmin kendisini daha çok bir "hareket" olarak tanımlamak yönündeki tavrı ve klasik-ortodoks örgütlenme biçimi karşısında duyduğu şüphe, "örgütlenmeye yapay bir süreklilik vermek" konusundaki gönülsüzlüğü (Woodcock, 1996, s. 22) anarşist fikirlerin güçlü bir teorik zemin kazanması ve yaygınlaşması yönünde bir engel oluşturmuştur.

\footnotetext{
${ }^{1}$ Bu eğilimin Türkiye için de geçerli olduğu söylenebilir. Küçük bir örnek olarak zikretmek gerekirse 28 Ocak 2018 tarihi itibariyle tez adları kriteri esas alınarak YÖK Tez Merkezi veri tabanına bakıldığında, ekolojik sorunları merkeze alan 2005 ve 2012 tarihli olmak üzere “Toplumsal Ekoloji” odaklı iki doktora tezi; 2006, 2010 ve 2015 tarihli olmak üzere “Derin Ekoloji" ve "Toplumsal Ekoloji" mukayesesine dayanan üç yüksek lisans tezi mevcut olduğu görülmektedir. Doğrudan "Derin Ekoloji”yi temel alan 2013 tarihli bir yüksek lisans tezi ve 2011 tarihli bir doktora tezi varken, “Ekoloji ve Anarşizm” başlıklı (2011) sadece bir adet yüksek lisans tezi mevcuttur. Söz konusu tartışmalar için kritik bir figür olan Murray Bookchin'i ise -yine tez adı temelinde- doğrudan ele alan 2011 tarihli tek bir yüksek lisans tezi vardır (Bkz. https://tez.yok.gov.tr/UlusalTezMerkezi/giris.jsp).
} 
Yirminci yüzyllla birlikte reel-politik sahnesinde yaşanan değişimler, SSCB'nin yıkılması başta olmak üzere reel sosyalizm deneyimlerinin genel başarısızlığı gibi dönüşümler, yeni toplumsal hareketlerin yükselişi, küreselleşme karşıtllğg ekseninde oluşan yeni muhalefet biçimleri ve politik hareketler temelinde anarşizm, temel kabulleri üzerinde yeniden düşünülmesi gereken bir düşünsel mecraya dönüşmüştür. Bu süreç aynı zamanda anarşizmin başka düşünsel pozisyonlar ve toplumsal hareketler ile iç içe geçmesinin de hızlandığı bir süreç olmuştur.

Küreselleşmenin temel dinamikleri, hem teori hem pratik alanında muhalefet hareketlerinin çeşitlendiği ve farklılaştı̆̆ 1 bir alan yaratmıştır. Hardt ve Negri'nin "politik bir özne" (Hardt ve Negri, 2003, s. 396) olarak öne ç1kardıkları, "asla hiyerarşik organlara bölünmüş birleşik bir bütün olmayacak çoğul bir bileşim"e (Hardt ve Negri, 2004, s. 208) ve "merkezi liderlik" gibi "geleneksel örgütlenme biçimlerinin geçersizliğine" işaret eden (Hardt ve Negri, 2011, s. 173) heterojen bir politik aktör olarak "çokluk" kavramsallaştırması gibi teorik girişimler, bu türden bir momente atıfta bulunur. Bu moment özelinde eko-anarşizm, eko-merkezli sorunların ekolojinin ve anarşizmin kabulleri üzerinden anlama ve açıklama çabasıdır. Söz konusu çaba, yine hem teorik hem de pratik alanında Hardt ve Negri'nin sözünü ettiği türden heterojen bir politik hareketin de kurulduğu zeminlerden biridir. Bu zemin, sadece ekolojinin değil, anarşizmin içindeki önemli teorik dönüşümlerin de hesaba katılması üzerinden eko-anarşizmin sınırlarına dair önemli ipuçları verecektir.

Buradan hareketle bu çalışmanın amacl; üzerinde yeterince durulmamış bir teorik mecra olarak postanarşizmin ya da bir başka deyişe postyapısalcı anarşizmin ekoloji düşüncesi için sunabileceği imkânlara yakından bakmaktır. Bu yapılırken, çalışmanın fiziki sınırları müsaade etmeyeceği için, ekoloji düşüncesinin tarihsel temelleri, anarşizmin gelişimi ya da eko-anarşizmin gelişim safhalarına dair bir tartışmaya girişilmeyecektir. İşaret edilen tartışma için kritik bazı temel noktalara kısaca ve çok genel hatlarıyla değinecek olan söz konusu çalışma, iki ana bölümden oluşmaktadır. İlk olarak tasvir edici ve tanımlayıcı bir perspektiften yola çıkarak postyapısalcı anarşizmin temel nitelikleri ve kabulleri üzerinde durulacak, takip eden bölümde ise postyapısalcı anarşizmin ekolojik tahayyül ve özelde eko-anarşizm tartışmaları için nasıl bir düşünsel yol haritası sunduğu meselesi ele alınacaktır. Çalışmanın temel argümanı; postyapısalcı anarşizmin, genelde ekoloji düşüncesinin özelde de eko-anarşizmin sınırlarını bilhassa özne 
teması üzerinden geliştirdiği anti-özcü yaklaşım üzerinden zenginleştirecek bir imkân sunduğudur.

\section{Postyapısalcı Anarşizm: Yeni Bir Meydan Okuma}

Tarihsel evrimi içinde her ne kadar William Godwin'in Siyasal Adalet Üzerine Bir Inceleme'si (An Enquiry Concerning Political Justice, 1793) anarşist temalara ev sahipliği yapan bir eser ve "felsefi anarşizmin temeli" olarak sıkça zikredilse de (Philp, 2017; Kropotkin, 2005, s. 56), anarşizm özü itibariyle ondokuzuncu yüzyılda sistematik bir hal almış bir ideolojidir. Esasen bireyci ya da kolektivist anarşizm perspektifleri, tıpkı muhafazakârlıkta olduğu gibi, Anglo-Amerikan dünyasında, Kıta Avrupası'nda ya da Rusya özelinde farklılaşsa da etimolojik doğasına uygun bir biçimde anarşizm, insanı ve onun özgürlük potansiyelini baskı altına alan her tür otorite ilişkisinin reddi olarak tanımlanabilir. Ancak, söylemeye bile gerek yok ki, "anarşizmin tek bir tanımı olmadığı gibi anarşizmin bir toplumsal formasyon olarak nasıl gerçekleştirilebileceğine dair tek bir ütopya da söz konusu değil"dir (Degen, 1999, s. 163). Sözgelimi bu çerçevede Kaufmann, "radikal, felsefi, elitist, iktisadi, cemaat" anarşizmleri ve "anarko-sendikalizm" temelinde anarşizmin çeşitliliğine vurgu yapar (Kaufmann, 2003, ss. 17-22).

Ondokuzuncu yüzyıldan yirminci yüzyıla uzanan bir hatta Emma Goldman, anarşizmi, "bireyin bütün gizil güçlerinin olabildiğince özgür biçimde ifade edilmesi" (Goldman, 2012, s. 19) ve "insanlığa ve onun potansiyellerine inanan" (Goldman, 2006, s. 4) bir dünya görüşü olarak tanımlarken, Kropotkin kavramı eşitlik ilkesi ekseninde tanımlayarak onu sadece "yönetilmeme arzusu" temelinde değil, ayn zamanda "yönetmemek arzusu" düzleminde düşünür (Kropotkine, 1999, s. 42) ve anarşizmin "toplumun yönetimsiz olarak tasarlandığ 1 bir yaşam ve davranış ilkesi" olarak "özgürlüğün, hiçbir iktidarın varlığıyla bağdaştırılamayacağg" kabulüne dayandığını belirtir (Kropotkin, 2005, s. 51, 109). Bellegarigue, anarşizm kavramını eşitlik ve özgürlük, kardeşlik ve dayanışma idealleri üzerinden "hükümetin yadsınması" (Bellegarigue, 2014, s. 15) şeklinde ele alır. Anarşizm hem Ortodoks Marksizm'in proletarya diktatörlüğü gibi "geçici" yönetsel uygulamalarına, merkezi otorite yapılarına, bizatihi Marx'a atfedilen "kutsal devletçilik" anlayışına (Bakunin, 1998, s. 239), hem de liberalizmin “Kişinin Ben olarak özgürce davranıp kendini kabul ettirmesi yerine aklı, aklın egemenliğini isteyen" (Stirner, 2013, s. 134) burjuvazi eksenindeki özgürlük ve rasyonalite merkezli tutumuna karşı çıkar. 
Tarihsel süreç içerisinde anarşizm kendi kabulleri üzerinden yeni meydan okumalarla karşılaşmıştır. Değişen iktidar yapılarından kaynaklanan bu meydan okumalar anarşizmi farklı biçimlerde okumanın imkânları üzerinde düşünmeyi zorunlu kılmıştır. Postanarşizm olarak da zikredilen postyapısalcı anarşizm işte tam da bu noktada karşımıza çıkmaktadır. Postyapısalcı anarşizm, en genel haliyle, postyapısalcı düşüncenin Michel Foucault, Gilles Deleuze, Felix Guattari, Jean-François Lyotard, Jacques Lacan gibi isimlerinin teorik katkıları üzerinden anarşizmi güncel sorunlara uyarlama gayreti olarak tanımlanabilir. ${ }^{2}$

Saul Newman'ın deyişiyle, postanarşizm "postyapısalc1lık/söylem çözümlemesinden elde edilen içgörülerin uygulanması ve geliştirilmesi sayesinde anarşist teorinin özcü ve diyalektik olmayan çizgiler doğrultusunda gözden geçirilmesi girişimi" olarak görülebilir (Newman, 2004b, s. 27). Newman'a göre "otoritenin ve tahakkümün reddi" (Newman, 2006, s. 244), anarşizm ve postyapısalcılık arasında ortak bir kurucu noktadır. Bu red gayreti çok farklı teorik mecralardan geçmiş olsa da postyapısalcı anarşizmin evrimi özelinde ABD'li anarşist aktivist-düşünür Hakim Bey'in 1987 tarihli bir yazısında altını çizdiği tespitin önemli bir çıkış noktası olduğu söylenebilir: "Anarşizm, kendini İsa'nın öğretilerine benzer bir materyalizmden ve 19. Yüzyılın bayağı, iki boyutlu bilimselliğinden sıyırmalıdır" (Bey, 2004, s. 21).

Yine Newman'ın deyişiyle, postayapısalcı anarşizmde söz konusu olan şey postyapısalcılığın özellikle Foucault merkezli iktidar analizinin anarşizmin klasik yaklaşımının sınırlarını zenginleştirmek için sunduğu imkândır ve bu çerçevede "hümanizm ve Aydınlanma'daki ontolojik temellerinden soyulmuş bir anarşizm" söz konusudur (Newman, 2004a, s. 5). Todd May de benzer bir noktaya temas ederek Foucault, Lyotard ve Deleuze'ün postyapısalcı anarşist perspektifi için belirleyiciliğinden söz eder (May, 2004, s. 16). Lewis Call'un postmodern anarşizm dediği bu anarşist perspektif, yine Call'un bakış açısıyla klasik anarşizmden üç noktada ayrılır: "Postmodern anarşizm, klasik anarşizmin kuşkulu biçimde birleştirilmiş öznesine karşı,

\footnotetext{
${ }^{2}$ Bu gayretin Türkiye'deki en önemli mecrasının ilk sayısı 2004 yılında çıkan Siyahî dergisi olduğunu söylemek mümkündür. Baykal'ın deyişiyle derginin "ilk sayısının içeriğine bakıldığında (dergi) bir tür 'postanarşist manifesto' olarak tanımlanabilir. Saul Newman, Todd May, Hakim Bey gibi yazarların doğrudan postanarşizmden bahseden yazarlarının çevirileri ile 'Nietzsche, Deleuze,Foucault ve Radikal Demokrasinin Öznesi' gibi doğrudan postyapısalcıkla ilgili yazılar" derginin sayfalarında kendine yer bulmuştur (Baykal, 2014, s. 12).
} 
öznenin anarşisini ilan eder. Postmodern özne çoğul, dağınık, ve (...) şizofreniktir ve öyle kalmalıdır", "Klasik anarşistin sermaye ve devlet takıntılarının aksine (...) postmodern anarşizm çok daha geniş ve nüanslara sahip bir iktidar anlayışı" na işaret eder ve son olarak "Marksizm ve klasik anarşizm burjuva ekonomi politiğinin dilini çok fazla sürdürürken, postmodern anarşizm radikal sembolik teoriye dayanan transsemiyotik bir devrim sunar" (Call, 2005, s. 111).

Tüm bu temel üzerinden bakıldığında postyapısalcı anarşizmin bizatihi postyapısalcılığ 1 "makro-siyasetlerin yerini mikro-siyasetlere biraktı̆̆ı" bir teorik perspektif olarak gördüğü ve bu çerçevede anarşizm ve postyapısalcllık arasında "temsili siyasal müdaheleyi reddetme" ekseninde bir ortaklık bulduğu söylenebilir (May, 2000, s. 14, 24). Newman da "katı ahlaki ve akılcı temellerden ziyade olumsallık ve karar verilemezliğe dayalı bir radikal siyaset biçimi" olarak postyapısalcılığı tanımlarken onun “yapının kendisinin belirli bir dereceye kadar başka güçlerce belirlendiğini düşünerek yapısalcılığın bir adım ötesine geçen", öznelerin "bir merkez tarafından değil, iktidar, söylemsel rejimler ve pratiklerin dağınık ve kararsız ilişkileri tarafından oluşturulduğu"nu ileri süren ve hem "Aydınlanma hümanizminin" hem de "yapısalcılığın hümanizm eleştirisinin" ortak noktası olan özcülüğü reddeden (Newman, 2006, s. 15, 42) bir düşünsel çerçeve olduğunu vurgular. Bu bağlamda ve son olarak bugün için "postanarşizmin sadece soyut radikal teoride değil, Halkın Küresel Hareketi (People's Global Action)" gibi yapılanmalar içinde de mevcut" (Adams, 2003, s. 5) olduğunu da kaydetmek gerekir. Bu çerçeveden hareketle sorulması gereken soru ise şudur: Acaba postyapısalcı anarşizm, ekolojik düşüncenin sınırları içinde bize nasıl bir imkân sunmaktadır?

\section{Postyapısalcı Anarşizm ve Ekolojik Düşüncenin Sınırları}

Ekoloji en genel haliyle eklektik bir karakter arz eden bir düşünsel sistematiğe işaret eder. Bu minvalde ve ekolojizm düşüncesi için de geçerli olabilecek bir biçimde Çoban, çevrecilik ideolojisinin eklemlenme pratiklerin söz ettiği çalışmasında söz konusu ideolojinin kurucu unsurları arasında "Endüstriyelizm eleştirisi ya da gelişmeye ve ilerlemeye bir sınır konması düşüncesinin, muhafazakârlıkta; merkeziyetçi ve hiyerarşik olmayan yapılara geçilmesi idealinin anarşizmde; tüketim toplumunun eleştirisinin Frankfurt Okulunda; 'yumuşak teknoloji' düşüncesinin Fritz Schumacher'de (1973); nüfus baskısı inancının Malthusçulukta bulunabileceği"ne değinir (Çoban, 2002, s. 8). 
Ekoloji düşüncesi içindeki bu çok unsurluluk hali, onun düşünsel zenginliğine ve eklemlenme kapasitesi üzerinden yeni sorunlar karşısında alabileceği yeni biçimlere işaret eder. Bu çerçevede ekoloji ile eklemlenme pratikleri üzerinden iç içe geçen ideolojik örüntülerden biri de anarşizmdir. Eko-anarşizm, ekolojinin ve anarşizmin kesiştiği bir dinamik olarak hem ekolojik düşünce içindeki tartışmaların hem de anarşizmin nihai politik ufkunun takip edileceği bir uğrağa atıfta bulunur ve "ekolojik bir görüş olmakla birlikte kendini çevrecilik ve diğer ekolojik görüşlerden ayırır" (Coşkun, 2010, s. 102).

Ekoloji ve anarşizm arasındaki bağın tarihsel nüveleri klasik anarşist düşünürlerin çalışmalarında zaman zaman kendisini gösterir. Bu minvalde Kropotkin dayanışmacı bir anarşist yaşam tarzını doğal yaşamdan çıkarsanabileceğini savunur ve bunun için "hayvanlar dünyasının en gelişmişleri olan maymun topluluklarının bile bize en çarpıcı dayanışma uygulamalarını sundukları" na (Kropotkine, 1999, s. 40) dikkat etmemiz gerektiğini ileri sürer. Ancak Turan'ın da işaret ettiği gibi, "eko-anarşistleri geleneksel anarşistlerden ayıran nokta, onların doğa-toplum ilişkilerini amaçlamalarıdır" ve "19. yüzyıldaki anarşist düşüncede doğaya ilişkin görüşlerin olduğu iddia edilse bile (bunun) temelde ekolojik bir yaklaşım olmadığı açıktır" (Turan, 2002, s. 214). Zira söz konusu düşünürler, Aydınlanma Çağı'nın düşünsel motiflerinden uzaklaşabilmiş değildirler ve kendinde bir tür "düşünsel ikilemin" taşıyıcısıdırlar. Bu açıdan Demirağ'ın da işaret ettiği gibi, "ilk kuşak anarşistler, bir yanları ile Aydınlanma düşüncesini, diğer yanları ile modern sanayi uygarlığının eleştirisine dayanan bir romantik pastoralliği yan yana düşünebilen" (Demirağ, 2017, s. 346) bir görünüm arz etmektedirler.

Dolayısıyla anarşizmin ekolojik düşünce ile olan yakınlığını sistematik bir temele oturması için yirminci yüzyılı beklemek gerekecektir. Çalışmanın başında sözünü ettiğimiz anarşizmin teoriden çok pratiğe yaslanan tarihsel eğilimini hatırlatan bir örnek olarak eko-anarşizmin öncü figürleri arasında zikredilebilecek Paul Robien bu bakımdan zikredilmeye değer bir örnektir. Robien "anarşist doğa teorisi ile doğanın ve insanın korunmasının ve ortaklaşmacı yaşamın sentezi"ni yapmaya çalışarak "ekmek, güneş, hava" temelli "yerleşim kurma eylemi"nin sözcüsüdür (Seitz, 1999, ss. 86-87). Robien'in eko-sosyalizme de göz kırpan radikal ekolojizmi, ekolojik hareket ve anarşist tahayyülün önemle altını çizdiği eylemsel potansiyeli barındırması açısından küçük ama anlamlı bir örnektir.

Bu tarihsel manzaradan hareketle, yine Demirağ'ı takip ederek söyleyecek olursak, "temelleri Bookchin tarafından atılan ekolojik anarşist felsefe, ekolojik düşünce ile anarşist düşünce arasında yakınlıklar olduğu ya da 
ekolojik sorunlara en iyi yanıtın anarşizm tarafından verilebileceği tespitine dayanır" ve "ekolojik krizin arka planında yatan temel nedeni 'egemenlik olarak tahakküm' kavramında arar" (Demiră̆, 2017, s. 347, 351).

Gerçekten de eko-anarşist düşüncenin kurucu figürlerinden biri olarak Murray Bookchin'in yaklaşımında insan-doğa ilişkisinin temel dinamiği tahakküm nosyonu üzerinden açıklanır (Tekeli ve Ataöv, 2017, s. 177). Bookchin' in toplumsal ekoloji perspektifi; ekolojik sorunların "kökleşmiş toplumsal sorunlar" dan doğduğunu (Bookchin, 2013a, s. 9), "doğayı tahakküm altına altına alma düşüncesinin insan insan üzerindeki tahakkümünden kaynaklandığını" ileri süren (Bookchin, 2013b, s. 61; Bookchin, 2013c, s. 62) ve bu çerçevede bizatihi devleti de "ancak tahakkümle uyumlu hale gelmeleri için geleneksel toplum, adet ve duyarlıklarının -insanlığın, kendisinin başlangıcını oluşturan organik toplumla tüm bağlarını yitirmesine yol açacak ölçüde- değiştirilmesinin ardından ortaya çıkabilmiş" (Bookchin, 2013d, s. 175) bir kurum olarak gören bir perspektiftir.

Bu noktada şunu anımsatmakta fayda vardır: Tıpkı tek bir anarşizm olmadığ1 gibi tek bir eko-anarşizm de yoktur. Bu çerçevede eko-anarşist düşünce içinde güçlü eğilimi temsil eden Bookchin'ci toplumsal ekoloji perspektifi ile biyobölgecilik (bioregionalism) zikredilebilir. Davidson'ı izleyerek söyleyecek olursak, "modern toplumun doğal temelinden kopuşuna odaklanmış bir eko-anarşizm türü" ve "kültürel ve ekonomik pratiklerimizin ekolojik sistemlerin devamı ile çatışmaya başladığını" savunan bir yaklaşım olarak biyomerkezcilik; toplumsal ekoloji ile ontoloji, etik ve topluluğun tanımları konusunda bir dizi uzlaşmazlık içindedir ve bu uzlaşmazlıklar arasında en önemlisi "siyasal örgütlenme" konusunda dügüumlenir. Zira "biyobölgeciler otarşi prensibine bağlıyken, toplumsal ekolojistler konfederal yapılanmaları savunurlar" (Davidson, 2009, ss. 49-50).

Bu paralelde eko-anarşist düşünce içinde "tüm ekolojik sorunların kökeninde ilerleme ve uygarlık fikrinin yattığını düşünen John Zerzan ve Derrick Jensen gibi anarko-ilkelci (anarcho-primitivist)" bir akımın da olduğunun altını çizmek gerekebilir (Hall, 2011:382). Anarko-ilkelci akım, uygarlık karşısında duyduğu memnuniyetsizliği ssrarla dile getirir ve modern zamanların dünyasını doğa ve kültür arasında herhangi bir ayrım gütmeksizin doğrudan ve tüm yönleriyle patolojik bulur. Bu bağlamda Zerzan'ın söyledikleri anımsanabilir: "Büyük ölçüde yabancılaşmamış insan yaşamının uzun sürmüş bir dönemi olarak insanın tarihöncesi çağına ait sürekli artan belgeler, savunulması mümkün olmayan modernitenin gün gibi ortadaki fiyaskolarının karşısında çırılçıplak durmaktadır" (Zerzan, 2013a, s. 
154). Yine benzeri bir hatta Zerzan "tekno-sermaye tarafindan yaratılan ve her şeyi silip süpüren mega-makinanın kökeninin bizzat uygarlığın kendisine, işbölümü ve evcilleştirme mantığından doğan ilerleme saplantısına dayandığı"nı (Zerzan, 2013b, s. 6) da ileri sürer.

Eko-anarşizmin aynı anda hem toplumsal ekolojiyi kapsayan hem de biyobölgecilik tartışmalarına uzanan kapsamlı görünümü içinde Zerzan'ın başını çektiği "ilkelci" akım kapsamında değerlendirilebilecek bir kavram olarak "yeşil anarşizm" den de bahsetmek mümkün olabilir. Parson'ın belirttiği üzere, "Anarşist düşünce içinde çevresel yıkımın ve insanın boyunduruk altına alınmasının nedeni olarak, evcilleştirmeyle birlikte, uygarlığ gören" bir akıma atıfta bulunan "yeşil anarşizm" çerçevesinde ileri sürülen fikirlerin, derin ve toplumsal ekoloji teorilerinin aksine, yaygin ve sistematik bir biçimde karşımıza çıkmamasının nedeni; "yeşil anarşizm" hareketi içinden gelen aktivistlerin söz konusu fikirlerini -daha çok anarşist gruplar içinde dolaşımı olan- fanzinlerde ve müstear isimlerle paylaşması olarak gösterilebilir (Parson, 2007, s. 5).

"Yeşil anarşizm" in derin ekoloji ve toplumsal ekoloji yaklaşımlarıyla kıyaslandığında ayrıksı bir görünüm sunduğu ifade edilebilir. Bu çerçevede söz konusu üç yaklaşımın hem eko-merkezli sorunların niteliğine, hem de analiz düzeyine ve geliştirilebilecek politikalara dair farklı tespitleri vardır. Yine Parson'ın (2007, s. 7) oluşturduğu ve aşağıda sunulan sunulan tablo bu noktada işlevsel olabilir:

\begin{tabular}{|l|l|l|l|}
\hline & \multicolumn{1}{|c|}{ Derin Ekoloji } & \multicolumn{1}{|c|}{$\begin{array}{c}\text { Toplumsal Eko- } \\
\text { loji }\end{array}$} & \multicolumn{1}{|c|}{ Yeşil Anarşizm } \\
\hline Asıl Sorun & İnsan/Doğa İkiliği & Hiyerarşiler & Uygarlık \\
\hline $\begin{array}{l}\text { Modern Top- } \\
\text { lumda Sorunun } \\
\text { Aldığı Görünüm }\end{array}$ & $\begin{array}{l}\text { Ekonomik Ge- } \\
\text { lişme/İnsan Kibri }\end{array}$ & Kapitalizm & $\begin{array}{l}\text { Teknoloji/Isçiçilik } \\
\text { (Workerism) }\end{array}$ \\
\hline Analiz Düzeyi & Bireysel & Sistematik & Sistematik ve Bireysel \\
\hline $\begin{array}{l}\text { Değişim Taktik- } \\
\text { leri }\end{array}$ & $\begin{array}{l}\text { Kişisel Tefek- } \\
\text { kür/Doğrudan Ey- } \\
\text { lem }\end{array}$ & $\begin{array}{l}\text { Doğrudan Ey- } \\
\text { lem/Kitlesel Ör- } \\
\text { gütlenme }\end{array}$ & $\begin{array}{l}\text { Doğrudan Eylem/Ki- } \\
\text { şisel Tefekkür (Yeni- } \\
\text { den Yabanıllaşma) }\end{array}$ \\
\hline
\end{tabular}

Bu tabloyu akılda tutarak postanarşizmi eko-merkezli sorunlara yaklaşımı temelinde sınıflandırmak anlamlı olacaktır. Her şeyden önce postanarşizm, "Aydınlanma ve onun özne merkezli anlayışına eleştirel bir mesafe koymayı başararak", "aklın, dar bir rasyonalizme saplanmadan manevi bir içerimle de irtibat halinde olabileceği genişletilmiş bir akıl yaklaşımı" üzerinden ve "özne yerine hareket olgusuna dikkat çekerek sunduğu felsefi 
önermelerle Murray Bookchin'in "insan-merkezci" ve kayda değer bir biçimde "determinist" yaklaşımına eleştirel bir tutum alışa işaret eder (Demirağ, 2017, ss. 360-362, 375). Örneğin bu çerçevede, Hall, Bookchin'in konumunu "insanın ve aklın önceliğine yapılan vurgu nedeniyle eko-anarşistten çok eko-hümanist olarak değerlendiren" yaklaşımların varlığına dikkat çeker (Hall, 2011, s. 381).

Bu noktada postyapisalcı anarşizmin; eşzamanlı olarak derin ve toplumsal ekolojinin özcü yaklaşımlarından ayrıldığı, hem derin ekolojin hem de toplumsal ekolojin yeterince hesaplaşamadığı Aydınlanma mirasına karşı daha eleştirel bir konum arz ettiği ve her iki yaklaşımında da izleri sürülebilecek insan doğasına dair varsayımlardan uzak durmak konusunda daha güçlü bir potansiyele işaret ettiği ifade edilebilir. Anarko-ilkelcilik veya "yeşil anarşizm" in radikal uygarlık eleştirisinin taşıdığı aşırı basitleştirmeci ve genellemeci eğilim de postyapısalcılığın iktidarı tek bir merkezde ve dikey bir hat üzerinden düşünmemek konusundaki tavrı üzerinden yine eleştirel bir biçimde değerlendirilir. Şu halde postyapısalcı anarşizm, öncelikli olarak, eko-merkezli sorunları tek bir nedenle açıklamak isteyen kapsayıcı eğilimleri mikro-iktidar pratiklerinin alanına çağırmak imkânına işaret ettiği için özellikle anlamlı ve önemlidir. Daha spesifik olarak ifade etmek gerekirse, derin ekolojinin eleştirisini sunduğu yüzeysel ekolojik eğilimin veya çevreciliğin, toplumsal ekolojinin eleştirel bir zaviyeden yaklaştığ1 kapitalizmin ve bilimsel sosyalizmin eleştirisi; nihayetinde iktidarı hep bir merkezden hareketle tarif eder ve onu merkezden yayılan hiyerarşik bir etki, statik bir yapı olarak ele alır. Bu, eko-merkezli sorunları mikro-siyaset alanında, kişisel ilişkilerde, özel alanda üreten yatay dinamikleri ıskalama riskine kapı açan bir tutumdur. Bir başka deyişle, postanarşist bir ekolojik anlayış, diğer ekolojik yaklaşımlardaki haliyle "büyük ve kapsayıcı bir konum" olarak iktidar anlayışının reddine dayanacaktır. Postanarşist ekolojik yaklaşım, eko-merkezli tahayyülün doğasına da uygun bir biçimde iktidar analizinde ilişkiselliğe odaklanması açısından dikkate değer bir görünüme sahiptir.

\section{Sonuç}

Bir Osmanlı aydını olan Baha Tevfik'in yirminci yüzyılın ilk çeyreğinde basılan metni Felsefe-i Ferd'de anarşizm, "bireyin özgün meziyetlerine karşı olan bütün güçleri mahvetmek" ve "bireyin üzerinde doğa yasalarından başka bir yasa bırakmamak" şeklinde tanımlanır (Tevfik, 1997, s. 111). 
Tevfik'in bu Aydınlanmacı anarşizm tanımı uzun bir süre anarşist düşüncenin güçlü eğilimlerinden biri olmuştur. Ancak tarihin akışı, anarşizm için yeni meydan okumalar sunmuş; bu meydan okumaların bir diğer muhatabı olan ekolojik düşünce de, tıpkı feminizm ya da muhafazakârlıkla olduğu gibi, anarşizm ile de iç içe geçmek eğiliminde olmuştur.

Bu çerçevede yirminci yüzyılın ikinci yarısında daha çok Fransa merkezli gelişen postyapısalcılık, anarşizm için yeni bir yüzyılın başlangıcında ilham verici bir "yeniden başlama" mecrası olmuştur. Bu mecranın üzerinde düşünme çabası, bir yandan postyapısalcı anarşizmin gelişimine bir yandan da eko-anarşizmin bu yeni akımdan neler öğrenebileceğine dair bir dizi soruyu doğurmuştur. Bu eksende hareket eden söz konusu çalışma, kendi sınırlılıkları içinde, postyapısalcı anarşizmin üzerine inşa edilecek bir ekolojik bakışın hümanizm, Aydınlanma ve özne sorunlarını yeniden düşünmek temelinde ekolojik tahayyül için bir dizi imkâna işaret edebileceğini göstermeye çalışmıştır. Hiç kuşku yok ki, bu imkânlar başka eleştirel perspektifler üzerinden yeni okumalara her zaman açıktır.

Buradan hareketle postyapısalcı anarşizmin üç temel noktada ekolojik tahayyülün sınırlarını genişletmek konusunda güçlü bir potansiyel taşıdığı iddia edilebilir. Birincisi derin, toplumsal ya da "yeşil anarşizm"den farklı olarak postyapısalcı anarşist ekolojik tahayyül, sabit bir insan doğası nazariyesini kendisi için kurucu bir başlangıç noktası kabul etmez. Nitekim ekolojik sorunları insanın "şimdi ya da geçmişte" sahip olduğu otantik bir öz ile sabitlemek, ekolojik sorunları metafizik sorunlar olarak görmek riskini doğurmaktadır. Bu minvalde postyapısalcı anarşizmin; insana bir öz atfetmek konusunda anarşist gelenekten de ayrıldığını, bizatihi bu "insan özü" kavramsallaştırmasına eleştirel baktığını ve bu haliyle de esasen bir hümanizm eleştirisi olarak karşımıza çıktığını zikretmek gerekmektedir (May, 2000, s. 25, 94). Postyapısalcı anarşizme dayanan bir ekolojik yaklaşım, bu türden bir hümanist eğilimin ekolojik düşüncenin sınırlarını insan doğası sorunundan kalkarak kurması karşısında eleştirel bir düşünce imkânı anlamina gelecektir.

İkinci bir husus, postyapısalcı bir anarşist tahayyülün zorunlu olarak bir Aydınlanma eleştirisi ya da May'in deyişiyle "Aydınlanma'yı sorgulamayı" (May, 2000, s. 171) gerektirmesidir. Yukarda da vurgulandığı üzere, "anarko-ilkelci" ya da "yeşil anarşist" eğilimin Aydınlanma'yı uygarlık nosyonu üzerinden tamamen reddetmesi, ya da Bookchin'in Aydınlanma'yı salt ilerleme ve modernite bağlamında düşünen indirgemeci pozisyonu veya Aydınlanma'da bir dizi düalizm üreten bir öz bulma fikri 
üzerinden işleyen derin ekoloji perspektifi düşünüldüğünde postyapısalcı anarşizm temelli bir ekolojik yaklaşım, Aydınlanma ile "topyekun bir red" ilişkisi kurmayacağı gibi onu belirli bir özle de tanımlamaktan uzak duracaktır. Bu, eko-merkezli sorunları düşünmek için Aydınlanma ile daha soğukkanlı bir ilişkinin temellerini atması açısından önemli bir düşünsel tavır olsa gerektir. Zira Aydınlanma, salt bir red ya da onay ilişkisine indirgenemeyecek kadar çok katmanlı bir çerçeve arz eder. Bu çerçeveyle kurulacak eleştirel mesafenin inşa edilmesinde zikredilen yaklaşım üzerinde düşünmeye değer bir imkan sunabilir.

Son olarak postyapısalcı anarşizm eksenindeki bir ekolojik yaklaşım, özne sorununu düşünmek için de dikkate değer bir imkân sağlamaktadır. Bookchin'in neolitik çağ romantizmi, derin ekolojistlerin gönülsüz modernizmleri ya da anarko-ilkelcilerin radikal anti-uygarlık projesi özneyi tıpkı iktidar nosyonunda olduğu gibi tek ve bütün bir yapı olarak değerlendirmek eğilimindedir. Bu eğilim, dolaylı olarak eko-merkezli sorunlar için çizilecek mücadele perspektifi için bir "ideal aktör" aramak girişimine kapı aralamaktadır ve bu arayışın nihai ve gerçekten etkin bir adresi olduğunu söylemek zordur. Bu çerçevede postyapısalcı anarşizm eksenindeki bir ekolojik yaklaşım, çok boyutlu yapısı ile eko-sosyalizm ya da eko-feminizm gibi akımlarla eleştirel bir işbirliği geliştirebilir. Tam da bu noktada örneğin “devrimci öznenin, bizim şimdiye kadar kullandığımız proleterya kavramının ve onun kavramsal çerçevesinin sunduğu beklentiler doğrultusunda 'işlemediği'"'ni savunan Bahro'nun, "Avrupa işçi sınıfının insanlığın bütün geri kalanıla örtüştüğü fikrinin geçersizliği"nden söz ederek bu anlamda sinıf kategorisinin "artık gerçekten eylem üreten birim olarak kavranamayacağı" na (Bahro, 1996, ss. 62, 96-97) işaret eden yaklaşımı - en azından söz konusu sorunun pratikteki seyri düşünüldügüünde- anımsatılabilir. Bu türden bir yaklaşıma ters düşmeyen bir biçimde postyapısalcı anarşist ekolojik yaklaşım, özneyi tüm heterojenliğiyle ve tüm toplumsal ve coğrafi-kültürel katmanlarda ele alarak diğer ekolojik yaklaşımların tam olarak kaçamadığı Avrupa-merkezci yaklaşıma karşı da mesafeli bir duruş geliştirmek potansiyelini bünyesinde barındırmaktadır. 


\title{
Extended Abstract
}

\section{Poststructuralist Anarchism and Ecology}

\author{
Seçil Mine Türk \\ Gazi University
}

Ecological thought has an important place in the literature of political science and political theory. Especially in the 70s, the environmental protectionist movement has been replaced by the ecology movement. The environmentalist movement, whose main idea is the protection of natural resources and the provision of ecological balance, has a more individual, institutionalist and environmentalist perspective. It does not establish a direct link between the deterioration of the environment and the basic values of society or people's view of nature. Environmental problems are seen as a natural consequence of human activities. The important point here is to minimize these problems. It accepts existing social order and according to this movement there is no need to change social or economical values. The environmental problems can be solved by not changing the society but by correcting them after problems arise.

With the new social movements like peace or women movement, also the environmental movement aims the protection of the environment has gained a more massive appearance. In particular, all groups involved in these movements took part in the ecological movement and began to look for the real causes of the problems in the social structure. On the other hand, with this transition, the identity of environmental protective action changed. The ecological movement begins to criticise the dominant paradigm, the lifestyles of people, social institutions and the social structure. This movement examines not only the basic values of society, but also the political order, the state structure, and the basic institutions of the state. In this context, it advocates smaller-scale habitats and localization. In this respect, ecological thinking has started to find and change the underlying causes of environmental problems. 
With the emergence of the political aspect of environmental problems, ecological thought is divided into some branches such as ecofeminism, ecosocialism ecofascim and ecoanarchism. All these approaches draw attention to the main causes of environmental problems and interested in the main factors that reveal these problems. In this context, these approaches, which are seen as a combination of political theory and ecology theory, try to find a solution to environmental problems by including the basic elements of human and environmental relations. The common point of all these approaches is that they emphasize mental and social processes rather than concrete reasons like industrialization or urbanization underlying these environmental problems. At the core of these approaches to environmental problems, there is the assumption that social structures should be rewieved, the perception of nature should change and the social relations between people and nature must be rearranged. This change is considered to be the most fundamental condition for solving problems.

In terms of these basic approaches of ecological thought, domination and hierarchy are the basis of all problems. In this process starting with the idea of Enlightenment, with the power of mind people see themselves superior to the other creatures and more valuable than others. This thought gives humans the right to manage all living and non-living things according to their self interests.

The post-structuralist anarchism and ecological thought, which form the basis of our subject, focus on environmental issues on a common ground and focused on the social and cultural processes that underlie the environmental problems. The social problems accepted in anarchist thought also emerge as basic problems in ecological thought. These problems affect the ecological balance, humans and the security of state. Natural resources are the main reasons of the interstate conflicts that emerged throughout history. The basic necessity in addressing environmental problems is to ensure that people live in a healthier environment. On the other hand, the elimination of environmental problems will also ensure the safety state. It will not be possible to solve environmental conflicts without changing the structure of society.

In this context, ecological thought, just as in the idea of anarchism, argues that the desire to dominate is the main reason of ecological problems. The idea of anarchism the domination of people over the others is accepted in line with the desire to dominate the nature in ecological thought. The idea that human beings, especially with the idea of enlightenment, is 
superior to other beings in nature, the natural resources are used in accordance with their own wishes to dominate the nature. People before this period who lived in harmony with nature began to question their sovereignty over nature. With scientific and philosophical developments, they began to use their mind to dominate nature.

As a result poststructuralist anarchism can be claimed to have a strong potential to expand the boundaries of ecological thought with the ideas of humanizm, Enlightenment, the ideas of exploitation and sovereignty.

\section{Kaynakça/References}

Adams, J. (2003). Postanarchism in a nutshell. 3 Ocak 2018 tarihinde https://theanarchistlibrary.org/library/jason-adams-postanarchism-in-a-nutshell.pdf adresinden erişildi.

Bahro, R. (1996). Nasıl sosyalizm? hangi yeşil? niçin tinsellik? (T. Bora, Çev. ve Der.). İstanbul: Ayrıntı Yayınları.

Bakunin, M. (1998). Devlet ve anarşi. (M. Uyurkulak, Çev.). Ankara: Öteki Yayınevi.

Baykal, E . (2014). Türkiye'de anarşist yazının gelişimi ve siyahi dergisi. Marmara Iletişim Dergisi, 13 (13), 1-19.

Bellegarigue, A. (2014). İlk anarşist manifesto. (B. Taneri, Çev.). İstanbul: Altıkırkbeş Yayin.

Bey, H. (2004). Postanarşizm anarşi (D. Sandalcı, Çev.). Siyahî, 1, 18-21.

Bookchin, M. (2013a). Toplumsal ekoloji ve komünalizm. (F. D. Elhüseyni, Çev.). İstanbul: Sümer Yayıncilik.

Bookchin, M. (2013b). Toplumu yeniden kurmak. (K. Şahin, Çev.). İstanbul: Sümer Yayinclik.

Bookchin, M. (2013c). Ekolojik bir topluma doğru. (A. Yllmaz, Çev.). İstanbul: Sümer Yayıncilik.

Bookchin, M. (2013d). Özgürlüğün ekolojisi: hiyerarşinin ortaya çıkışı ve çözülüşü. (M. K. Coşkun, Çev.). İstanbul: Sümer Yayıncılık.

Call, L. (2005). Postmodern matris. (S. Evren, Çev.). Siyahî, 2, 82-91. 4 Ocak 2018 tarihinde ttps://docs.google.com/file/d/0B3UlnTbin7cnTjk5YXItTmZUTEE/edit adresinden erişildi.

Coşkun, S. (2010). Çevre sorununa radikal bir çözüm önerisi olarak eko - anarşizm. Kaygi, 15, 101-116.

Çoban, A. (2002). Çevreciliğin ideolojik unsurlarının eklemlenmesi. Ankara Üniversitesi SBF Dergisi, 57 (3), 3-30.

Davidson, S. (2009). Ecoanarchism: a critical defence. Journal of Political Ideologies, 14(1), 47-67. 
Degen, H-J. (1999). Anarşizmin bir geleceği var mı? Birkaç not. (N. Ozan, Çev.). H. J. Degen (Der.). Anarşizmin bugünü: tavırlar içinde (ss. 77-98). İstanbul: Ayrıntı Yayınları.

Demirağ, D. (2017) Doğayı yardıma çağırmak: Anarşist ekolojizm. O. İmga ve H. Olgun (Ed.). Yeşil ve siyaset: siyasal ekoloji üzerine yazllar içinde (ss. 331-385). Ankara: Liberte Yayınları.

Goldman, E. (2006). Dans edemeyeceksem bu benim devrimim değildir. (N. Bayram, Çev.). İstanbul: Agora Kitaplığı.

Goldman, E. (2012). Anarşizm neyi savunur?. (D. Kömürcü, Çev.). İstanbul: Agora Kitaplığı.

Hall, M. (2011). Hall (2011) Beyond the human: extending ecological anarchism. Environmental Politics, 20:3, 374-390.

Hardt, M. ve Negri, A. (2003). Imparatorluk. (A. Yılmaz, Çev.). İstanbul: Ayrıntı Yayınları.

Hardt, M. ve Negri, A. (2004). Çokluk. (B. Yıldırım, Çev.). İstanbul: Ayrıntı Yayınları.

Hardt, M. ve Negri, A. (2011). Ortak zenginlik. (E-B. Yıldırım, Çev.). İstanbul: Ayrıntı Yayınları.

Kaufmann, M. (2003). Aydınlanmış anarşi: siyaset felsefesine giriş. (Y. Coşar, Çev.). İstanbul: Ayrıntı Yayınları.

Kropotkine, P. (1999). Anarşist etik. (I. Ergüden, Çev.). Ankara: Doruk Yayımcılık.

Kropotkin, P. (2005). Anarşi: felsefesi-ideali. (I. Ergüden, Çev.). İstanbul: Kaos Yayınları.

May, T. (2000). Postyapısalcı anarşizmin siyaset felsefesi. (R. G. Öğdül, Çev.). İstanbul: Ayrintı Yayınları.

May, T. (2004). Postyapısalcı anarşizm sahaya iniyor. (Söyleşi S. Evren vd.). Siyahî, 1, 12-17.

Newman, S. (2004a). Radikal demokraside yeni tahayyüller. (Söyleşi S. Evren vd.). Siyahî, 1, 4-11.

Newman, S. (2004b). Postanarşizmin siyaseti. (K. Kızıltuğ, Çev.). Siyahî, 1, 22-29.

Newman, S. (2006). Bakunin'den lacan'a: anti-otoriteryanizm ve iktidarın altüst oluşu. (K. Kızıltuğ, Çev.). İstanbul: Ayrıntı Yayınları.

Parson, S. (2007). Eco-anarchism rising: the earth liberation front and the formation of revolutionary environmentalism. 20 Ocak 2018 tarihinde http://195.130.87.21:8080/dspace/bitstream/123456789/342/1/EcoAnarchism\%20Rising.\%20The\%20Earth\%20Liberation $\% 20$ Front $\% 20$ and $\% 20$ the $\% 20$ for.pdf adresinden erişildi.

Philp, M. (2017). William Godwin. The Stanford Encyclopedia of Philosophy. 11 Ocak 2018 tarihinde https://plato.stanford.edu/entries/godwin/ adresinden erişildi.

Seitz, G. (1999) Anarşi ve Komün. (N. Ozan, Çev.). H. J. Degen (Der.). Anarşizmin bugünü: tavırlar içinde (ss. 77-98). İstanbul: Ayrıntı Yayınları.

Stirner, M. (2013). Biricik ve mülkiyeti. (S. T. Noyan, Çev.). İstanbul: Kaos Yayınları. 
Tekeli, İ. ve Ataöv, A. (2017). Sürdürülebilir toplum ve çevre: stratejiler yelpazesi. İstanbul: İstanbul Bilgi Üniversitesi Yayınları.

Tevfik, B. (1997). Felsefe-i ferd: anarşizmin Osmanlıcası. (B. Şaylı, Çev.) İstanbul: Yumuşak G Yayınları.

Turan, F. (2002). Eko-anarşizm: yeşil alternatif. Düşünen Siyaset, 11, 213-224.

Woodcock, G. (1996). Anarşizm: bir düşünce ve hareketin tarihi. (A. Türker, Çev.) İstanbul: Kaos Yayınları.

Zerzan, J. (2013a). Niçin ilkelcilik?. Makinelerin Alacakaranlığı: Makaleler (R. G. Öğdül, Çev.) içinde. İstanbul: Kaos Yayınları.

Zerzan, J. (2013b). Gelecekteki ilkel (C. Atila, Çev.). İstanbul: Kaos Yayınları.

Dr. Öğr. Üyesi Seçil Mine Türk, Bilkent Üniversitesi İktisadi, İdari ve Sosyal Bilgiler Fakültesi Siyaset Bilimi ve Kamu Yönetimi Bölümü'nde lisans, Ankara Üniversitesi Sosyal Bilimler Enstitüsü Kent ve Çevre Bilimleri anabilim dalında yüksek lisans ve doktora eğitimini tamamladı. Halen Gazi Üniversitesi İktisadi ve İdari Bilimler Fakültesi Siyaset Bilimi ve Kamu Yönetimi Bölümü'nde yardımcı doçent olarak görev yapmaktadır. İlgi alanları; kentleşme politikaları, çevre politikaları ve yerel yönetimlerdir.

Dr. Seçil Mine Türk, Seçil Mine Türk holds a B.Sc. in Political Science and Public Administration from Bilkent University, an M. A and a Ph.D. in Environmental Social Sciences from Ankara University. She works as an Assistant Professor in the Department of Political Science and Public Administration at Gazi University in Ankara. Her major research interests include politics of environment, urban politics and local administrations.

\section{Kaynakça Bilgisi / Citation Information}

Türk, Ş.M. (2018). Postyapısalcı Anarşizm ve Ekoloji. IDEALKENT - Kent Araştırmaları Dergisi, 24, 644-661. 